\title{
Obchody Święta Niepodległości i rocznicy wybuchu powstania wielkopolskiego w środowisku byłych powstańców w Wielkiej Brytanii 1940-1989
}

\begin{abstract}
Abstrakt: W artykule przedstawiono działalność byłych powstańców wielkopolskich, którzy po zakończeniu działań wojennych w 1945 r. znaleźli się na Wyspach Brytyjskich. Pojawili się tam w wyniku ewakuacji Wojska Polskiego po upadku Francji, z Polskich Sił Zbrojnych na Zachodzie, jak też z niemieckich obozów jenieckich, z których zostali uwolnieni w latach 19441945. Środowisko to wykazało dużą aktywność polityczną i społeczną, angażując się w upamiętnienia rocznic narodowych. Szczególny nacisk kładli na kultywowanie wielkopolskiego czynu niepodległościowego w XIX w. oraz ukazanie genezy, przebiegu i znaczenia powstania wielkopolskiego 1918-1919.
\end{abstract}

Słowa kluczowe: obchody rocznic narodowych, uchodźstwo polskie w Wielkiej Brytanii, powstanie wielkopolskie, 15 Pułk Ułanów Poznańskich, gen. Władysław Anders.

Abstract: The article presents the activities of former Greater Poland insurgents who, after the end of the war in 1945, found themselves in Great Britain. They arrived there as a result of the evacuation of the Polish Army after the fall of France, as members of the Polish Armed Forces in the West, or came from German prisoner-of-war camps from which they were released in 1944-1945. This community was characterised by great political and social activity, and engaged in commemoration of national anniversaries. Particular emphasis was placed on cultivating the Greater Poland independence actions of the nineteenth century and on demonstrating the origins, course and significance of the Greater Poland Uprising of 1918-1919.

Key w or d s: celebrations of national anniversaries, Polish emigration in Great Britain, Greater Poland Uprising, 15th Poznań Uhlans Regiment, Gen. Władysław Anders. 
Lata wojny i okupacji 1939-1945 były okresem niezwykle dramatycznym także dla weteranów powstania wielkopolskiego. Część zmobilizowanych do Wojska Polskiego znalazła się w niemieckich obozach jenieckich i podlegali konwencjom międzynarodowym, w zasadzie przestrzeganym przez Niemców, zapewne obawiających się odwetu na niemieckich jeńcach wojennych znajdujacych się w alianckich obozach.

W okresie niemieckiego Zarządu Wojskowego (do 23 X 1939 r.) na Pomorzu, Wielkopolsce i Śląsku niemieckimi represjami objęci zostali byli powstańcy, jak też członkowie organizacji uznanych przez okupantów za wrogie wobec Niemców, zwłaszcza Polskiego Związku Zachodniego.

Do wybuchu wojny niemiecka V kolumna w Wielkopolsce prowadziła szeroką działalność szpiegowską i sabotażowo-dywersyjną. Mniejszość niemiecka oddała aparatowi hitlerowskiemu nieocenione wprost „usługi”, opracowując przez wiele lat wykazy najbardziej czynnych Polaków, m.in. byłych powstańców wielkopolskich, działaczy gospodarczych, społecznych, ludzi nauki i kultury itp. Na podstawie tych list już w pierwszym okresie okupacji hitlerowcy zamordowali kilkuset działaczy polskich. Agenci hitlerowscy przeniknęli do wielu polskich organizacji i instytucji, np. do Związku Powstańców Wielkopolskich (ZPW), Federacji Polskich Związków Obrońców Ojczyzny, Związku Nauczycielstwa Polskiego, Uniwersytetu Poznańskiego itd. Fakt ten dla polskich władz bezpieczeństwa nie stanowił tajemnicy. Edmund Męclewski pisał, że w powiecie ostrzeszowskim „Niemcy miejscowi w sasiedzkich pogwarkach odgrażają się, iż prowadzą u siebie kartotekę powstańców wielkopolskich i gdy przyjdzie czas to porachuja się z nimi”"

Agentura niemiecka skrzętnie rejestrowała informacje o udziale byłych powstańców w przygotowaniach do obrony Wielkopolski. Już 15 III 1939 r. $\mathrm{w}$ trakcie walnego zjazdu delegatów ZPW w obliczu zagrożenia wyrażono gotowość do obrony Ojczyzny, przeważały nastroje jedności i narodowego solidaryzmu. Apelowano o jedność w szeregach kombatanckich i „pogotowie narodowe" w szeregach powstańczych. W odezwie Zarządu Głównego (ZG) ZPW z 26 marca mówiło się o walce o byt i granice narodowe aż do ostatecznego zwycięstwa. Na łamach „Głosu Powstańca Wielkopolskiego” podkreślono, że bez walki Polska nie odda swych zachodnich ziem, a także Gdańska, „choćby przyszło cały kraj przemienić w gruzy i cmentarze, Polska nie ustapi nic ze swej wielkości i swej chwały"2.

W kwietniu prasa kombatancka i dzienniki poznańskie opublikowały apel kpt. Zdzisława Orłowskiego - prezesa ZPW: „Powstańcy!... [...] My powstańcy

\footnotetext{
${ }_{1}$ Zob. Archiwum Państwowe w Poznaniu (dalej: APP), Sicherheitsdienst Posen: Federacja Polskich Związków Obrońców Ojczyzny (sygn. 18), Związek Nauczycielstwa Polskiego (sygn. 15), Stronnictwo Narodowe (sygn. 16); E. Męclewski, Walka graniczna trwa, Poznań 1939, s. 77.

${ }^{2}$ APP, Związek Powstańców Wielkopolskich, 8, s. 11 i n.
} 
wielkopolscy okryci chwała czynu naszego zbrojnego historycznego patrzymy [...] z pełna gotowością oddania swego mienia i życia za honor i wolność Ojczyzny...”3

ZG ZPW zakładał wcielenie powstańców do oddziałów liniowych, formacji ochotniczych i oddziałów specjalnych, bezpośrednio podległych Samodzielnemu Referatowi Informacji DOK nr VII w Poznaniu. W końcu kwietnia 1939 r. ZG ZPW oddał do dyspozycji dowództwa DOK nr VII w Poznaniu członków organizacji w charakterze oddziałów ochotniczych. Wprawdzie władze wojskowe zaakceptowały propozycje, ale do utworzenia batalionów z byłych powstańców, tak jak na Śląsku, nie doszło. Organizacji powierzono natomiast zbieranie informacji na temat zachowania się niemieckiej mniejszości w rejonie pogranicza.

ZG ZPW polecił prezesom kół w okręgach: poznańskim, pomorskim i śląskim przygotowanie wykazów mobilizacyjnych członków organizacji do lat 40 (rezerwistów) i starszych w wieku od 40 do 50 lat, przeznaczonych do pomocniczej służby wojskowej. Opracowano też imienną ewidencję członków ZPW posiadających kwalifikacje na dowódców plutonów, kompanii i batalionów oraz podoficerów i oficerów łączności oraz ckm-ów ${ }^{4}$.

W sierpniu 1939 r. ZG ZPW ogłosił pogotowie ogólne. Zobowiązano zarządy kół do nawiązania kontaktów z komendantami powiatowymi wychowania fizycznego i przysposobienia wojskowego w sprawie objęcia przez byłych powstańców „służby wartowniczej i służby bezpieczeństwa”.

Byli powstańcy licznie zgłaszali się do tzw. żywych torped. Zapisy ochotników do oddziałów „żywych torped” miały jawny charakter. Akcja ta została zapoczątkowana 6 V 1939 r. przez krakowski „Ilustrowany Kurier Codzienny” i wiązała się z informacjami o japońskich ,żywych torpedach” w czasie wojny z Chinami. Był to więc typowy chwyt propagandowy, gdyż polski przemysł zbrojeniowy nie produkował tego rodzaju broni. W praktyce chodziło o uzyskanie ochotników do wykonywania zadań specjalnych. Z Wielkopolski zgłosiło się ogółem kilkuset ochotników ${ }^{5}$.

W trakcie wkraczania do Wielkopolski wojsk niemieckich w szeregu miejscowości opór Niemcom stawiały słabo uzbrojone oddziały samoobrony

3 „Dziennik Poznański”, 5 IV 1939, nr 79; APP, Związek Powstańców Wielkopolskich, 10, s. $20-21$.

${ }^{4}$ APP, Związek Powstańców Wielkopolskich, 8, Okólniki poufne nr 1 i 2.

${ }^{5}$ Ibidem, Okólnik specjalny z 31 VIII 1939 r. Na temat „żywych torped” zob. B. Polak, Społeczeństwo Wielkopolski w obliczu zagrożenia niemieckiego (kwiecień-sierpień 1939 r.), w: Udziat Wielkopolan w wojnie obronnej 1939 r., red. P. Bauer, Kościan 1975, s. 60-61. Antoni Hoffman, powstaniec wielkopolski i inwalida wojenny z Grodziska, 24 VIII 1939 r. przesłał marszałkowi Edwardowi Rydzowi-Śmigłemu projekt „żywej torpedy”, a właściwie miniaturowego okrętu podwodnego. Hoffman miał patent na działo przeciwlotnicze z 4 ruchomymi lufami (patent 27600 i 42818 z 23 XI 1938 r.). Uzyskał też patent na samoczynne ładowanie tego działa. Zob. Generalny Inspektorat Sił Zbrojnych, 302.2,21. 
podporządkowanej administracji zastępczej w miejsce ewakuowanych urzędów. Działania te zgodne były z prawem międzynarodowym. Do największych wystapień doszło w powiecie gnieźnieńskim, m.in. w Kłecku, Czerniejewie, Kiszkowie, Witkowie. Administrację zastępczą organizowali byli powstańcy, m.in. ks. mjr Mateusz Zabłocki - kawaler Orderu Virtuti Militari, Jan Bilski, kpt. dr Jan Zgaiński, ppor. Stanisław Sojka, kpt. Skibiński. W powiecie mogileńskim Strażą Obywatelską dowodził ppor. Kazimierz Nowicki. Oddziały samoobrony powstały też $\mathrm{w}$ powiatach śremskim, wrzesińskim, w Grodzisku, Międzychodzie, Sierakowie, Ostrowie Wlkp., Kępnie i innych. Do starć z oddziałami Wehrmachtu i Straży Granicznej oraz dywersantami doszło m.in. w Kłecku i 25 innych miejscowościach powiatu gnieźnieńskiego, w okolicy Inowrocławia, Mogilna i Trzemeszna, Murowanej Goślinie, Maniewie (pow. obornicki), Bojanowie Rawickim, Grabowie nad Prosna, Chlewie, Bukownicy, Dobrzycy ${ }^{6}$. W odwecie Niemcy wymordowali kilkuset rzeczywistych i domniemanych członków samoobrony. 12 X 1939 r. w więzieniu inowrocławskim zamordowany został ks. Zabłocki.

W czasie mobilizacji do Wojska Polskiego powołano wielu oficerów, byłych powstańców i żołnierzy Wojska Wielkopolskiego. Przydzieleni do oddziałów zapasowych w większości znaleźli się na obszarze wschodnich województw Rzeczypospolitej. Tam też zgłaszali się często oficerowie ochotnicy nieobjęci obowiązkiem mobilizacyjnym. Dzięki niestrudzonemu wysiłkowi Janiny Pańczakowej i Małgorzaty Cichoń, córce i wnuczce powstańca wielkopolskiego, powstała publikacja zawierająca ok. 250 biogramów byłych powstańców zamordowanych przez Sowietów głównie wiosną $1940 \mathrm{r}$.

Między innymi z Kozielska do lasu katyńskiego wywiezieni zostali mjr Władysław Wawrzyniak - dowódca odcinka południowego frontu wielkopolskiego, kawaler Orderu Virtuti Militari, ppłk Bronisław Piniecki - zdobywca lotniska na Ławicy 6 I 1919 r., kawaler Orderu Virtuti Militari, kpt. rez. Józef Mańczak, jeden z organizatorów lotnictwa powstania wielkopolskiego, kawaler Orderu Virtuti Militari, kpt. lek. Stanisław Owsiany.

\footnotetext{
${ }^{6}$ Szczegółowo na ten temat zob. B. Polak, Udziat ludności cywilnej w obronie Wielkopolski 1939, Koszalin 1989 - tamże źródła i literatura. Zob. też: A. Bernaś-Kostynowicz, Społeczeństwo polskie w wojnie obronnej 1939. Wspótdziałanie ludności cywilnej z wojskiem w okresie zagrożenia i działań wojennych, Warszawa 1978; Sz. Datner, 55 dni Wehrmachtu w Polsce. Zbrodnie dokonane na polskiej ludności cywilnej w okresie 1 IX-25 X 1939 r., Warszawa 1967; E. Dubas, Obrona cywilna Wielkopolski w 1939 r., w: Z lat wojny i okupacji, red. L. Grot, Warszawa 1974, s. 15-40; L. Gomolec, Obrona cywilna Kłecka w 1939 roku, Poznań 1966; J. Kaliska-Brzezichowa, Obrona Inowrocławia we wrześniu 1939 r. i poczatki okupacji hitlerowskiej (wrzesień-październik 1939 r.), „Zeszyty Naukowe INS” (Koszalin) 1986, z. 6; Ludność cywilna Kłecka w obronie Ziemi Gnieźnieńskiej. Studia z historii Ziemi Gnieźnieńskiej w latach 1919-1939, red. B. Polak, Poznań 1980; Zbrodnie Wehrmachtu w Wielkopolsce w okresie zarzadu wojskowego (1 września - 25 października 1939), red. A. Galiński i in., Kalisz 1986; K. Czechowska, Losy powstańców wielkopolskich ziemi szubińskiej w latach okupacji hitlerowskiej, „Wielkopolski Powstaniec” 2015.
} 
„Rozładowanie” obozu w Starobielsku rozpoczęło się w pierwszych dniach kwietnia 1940 r. Oficerów transportowano do Charkowa, skąd przewożono ich do więzienia NKWD i noca w piwnicach mordowano. Wśród oficerów znajdowali się także: ppor. dr Włodzimierz Lewandowski - bezsprzecznie najlepszy znawca dziejów powstania do 1939 r., ppłk Jan Chylewski - twórca artylerii ciężkiej wojsk powstańczych, dwaj oficerowie sztabu Dowództwa Głównego (DG) powstania: ppłk art. Adam Meissner i płk dypl. Alfons Wojtkielewicz, ponadto mjr art. Marian Taczak - bratanek gen. Stanisława Taczaka, ppłk dypl. Jerzy Skrzydlewski - oficer 1 (15) Pułku Ułanów Poznańskich, odznaczony Orderem Virtuti Militari. W obozie w Ostaszkowie m.in. osadzono ks. prałata płk. Czesława Wojtyniaka z 15 Pułku Ułanów Poznańskich, którego zamordowano w piwnicach więzienia NKWD. Nazwiska znanych powstańców wielkopolskich pomordowanych na Wschodzie można wymieniać jeszcze długo? ${ }^{7}$.

Wielu powstańców znalazło się pod okupacją niemiecką na tzw. ziemiach wcielonych do Rzeszy. Wielu było poszukiwanych przez Niemców na podstawie wcześniej sporządzonych list proskrypcyjnych.

Sicherheitsdienst (SD) - policja bezpieczeństwa posiadała doskonałe rozeznanie w środowiskach polskich organizacji w Wielkopolsce. Dokumentacja była bez przerwy uzupełniana dzięki dopływowi informacji od niemieckiej agentury. Dodawano do niej polskie akta zdobyte we wrześniu 1939 r. W ten sposób przejęte zostały wykazy członków wielu organizacji kombatanckich ${ }^{8}$.

Zarówno gestapo, jak i SD zdawały sobie sprawę z faktu, iż byli powstańcy mogą stanowić potencjalnych organizatorów antyniemieckiego ruchu oporu. Nic też dziwnego, że właśnie to środowisko było obiektem bezwzględnych prześladowań i eksterminacji. 3 X 1939 r. powstał obóz w poznańskim Forcie VII, 10 października przejęty od wojska przez SD. Miał on charakter przejściowy - więźniów przekazywano sądom, względnie do dużych obozów koncentracyjnych. W swojej istocie był to jednak obóz zagłady, gdyż wielu więźniów zamordowano, zginęli często w barbarzyński, wyrafinowany sposób. W Forcie VII więziono przede wszystkim polskich działaczy oskarżonych o działalność antyniemiecką.

Wielu byłych powstańców wraz z rodzinami wysiedlono do tzw. Generalnego Gubernatorstwa. W Archiwum Państwowym w Poznaniu znajdują się fragmenty akt dotyczących wysiedleń uczestników powstania wielkopolskiego. Między innymi 6 XII 1939 r. z Bydgoszczy wysiedlono 162 byłych powstańców, a z Inowrocławia - 124. Następnego dnia Poznań opuściło 125 osób,

\footnotetext{
7 Zob. Stownik biograficzny powstańców wielkopolskich 1918-1919, red. nauk. A. Czubiński, B. Polak, Poznań 2002; Powstańcy wielkopolscy. Biogramy uczestników powstania wielkopolskiego 1918-1919, red. nauk. B. Polak, t. I-XV, Poznań 2005-2018; K. Banaszek, W.K. Roman, Z. Sawicki, Kawalerowie Orderu Virtuti Militari w mogiłach katyńskich, Warszawa 2000; Materiały redakcji Stownika Biograficznego. Kawalerowie Orderu Virtuti Militari 1792-1945, Wydział Humanistyczny Politechniki Koszalińskiej.

${ }^{8}$ Zob. przypis 1.
} 
Śrem - 123, Leszno - 133, Rawicz - 199, Szubin - 102, Czarnków - 150 itd. 8 grudnia los ich podzieliło m.in. 174 powstańców z Krotoszyna, 105 z Nowego Tomyśla, 80 z Chodzieży, 85 ze Żnina, 119 z Gostynia i 766 z Poznania. Dzień później z Poznania wysiedlono 1162, a z Leszna - 195 osób.

Masowe akcje eksterminacyjne, wysiedlenia, obozy nie złamały ducha oporu społeczeństwa polskiego w Wielkopolsce. Jeszcze jesienia powstały pierwsze lokalne organizacje konspiracyjne. Większość z nich została utworzona z inicjatywy byłych powstańców, którzy z reguły stanęli na ich czele jako dowódcy. Wielkopolanie zachowali w pamięci nazwiska kpt. Leona Komorskiego, kpt. Leona Kmiotka, por. Stanisława Węcłasia, Mariana Winiewicza, ppor. Tadeusza Bączkowskiego, ks. inf. Józefa Prądzyńskiego.

Jesienią 1939 r. z Warszawy do Poznania zaczęli docierać emisariusze organizacji o zasięgu obejmującym ziemie Rzeczypospolitej w granicach z 31 VIII 1939 r.: Organizacji Orła Białego (OOB), Służby Zwycięstwu Polsce (SZP), następnie Związku Walki Zbrojnej (ZWZ).

W strukturach ZWZ, od lutego 1942 r. Armii Krajowej (AK) znaczącą rolę odegrali weterani powstania wielkopolskiego, m.in. mjr Stefan Effert (zam. 1944), płk Jan Namysł (zam. 1942), kpt. Franciszek Pawela (zam. 1942), mjr Wacław Kotecki (zam. 1943), kpt. Edward Bączkowski (zam. 1944), kpt. Wawrzyniec Mazany (zam. 1942), mjr hm. Związku Harcerstwa Polskiego Józef Ratajczak (zam. 1942) i inni9.

\section{Na Wyspach Brytyjskich ${ }^{10}$}

Na kresach Rzeczypospolitej od śmierci z ręki sowieckich oprawców uratowała się nieliczna grupa oficerów, którzy przez Węgry, Rumunię, Jugosławię dotarli do Francji, a po jej upadku do Wielkiej Brytanii. Tym, którzy więzieni byli w obozach na terenie Związu Sowieckiego, drogę do wolności otworzyły niemiecka agresja na ZSRS i układ polsko-sowiecki. Z wojskiem dowodzonym przez gen. Władysława Andersa przeszli szlak bojowy 2 Korpusu, a potem obozy Polskiego Korpusu Przysposobienia i Rozmieszczenia (PKPR) w Wielkiej Brytanii. Niewielu zdecydowało się na powrót do Polski pod sowiecka dominacja. Na Wyspach Brytyjskich spotkali się z Polakami, byłymi jeńcami z niemieckich obozów, którzy za drutami od 1939 r. oczekiwali na koniec wojny, a także z grupa, która po upadku Francji uczestniczyła w tworzeniu

${ }_{9}$ Zob. B. Polak, Powstańczy rodowód polskiej konspiracji wojskowej w Wielkopolsce, 19391942, w: Z dziejów polskiej konspiracji wojskowej na tzw. ziemiach wcielonych do Rzeszy 1939-1945, red. nauk. B. Polak, Koszalin 1988, s. 52-121.

${ }^{10}$ Szczegółowo zob. B. Polak, M. Polak, Obchody rocznic powstania wielkopolskiego $w$ Wielkiej Brytanii (cz. 1), „Wielkopolski Powstaniec” 2018, s. 54-71; iidem, Powstańcy wielkopolscy 1918-1919 po II wojnie światowej w Wielkiej Brytanii, „Wielkopolski Powstaniec” 2016, s. 34-45; cz. 2, 2017, s. 29-35. 
1 Korpusu Polskich Sił Zbrojnych (PSZ) - dywizji pancernej, brygady spadochronowej i innych jednostek.

Kilku oficerów przeszło wyjątkowo upokarzające doświadczenie: po dotarciu w latach 1939-1940 do Francji uznani zostali za stronników sanacji i osadzeni w obozach izolacyjnych we Francji (Cerizay), skąd w dniach jej klęski przewieziono ich na Wyspę Węży. Między innymi byli to kawalerowie Orderu Wojennego Virtuti Militari: mjr Mieczysław Paluch, mjr dr med. Wojciech Jedlina-Jacobson - jeden z dowódców powstańców gnieźnieńskich. Major Zdzisław Orłowski, w powstaniu m.in. dowódca IV Okręgu Wojskowego, we Francji został wyznaczony na komendanta obozu w Cerizay.

$\mathrm{Z}$ oficerami na Wyspie Węży wiąże się 1 . rocznica wybuchu powstania wielkopolskiego, którą obchodzono w Wielkiej Brytanii. 27 XII 1940 r., z inicjatywy biskupa polowego Józefa Gawliny w szkockim mieście Perth, w katolickim kościele pw. św. Jana odbyły się uroczystości w 22. rocznicę wybuchu powstania w Wielkopolsce. Rozpoczęły się one mszą św. Nabożeństwo odprawił ks. bp WP Gawlina. Przybyli prezydent RP Władysław Raczkiewicz, premier i Naczelny Wódz gen. Władysław Sikorski, generalicja, członkowie Rady Narodowej, powstańcy wielkopolscy i ślasscy. Na uroczystość przepustkę otrzymali mjr Paluch i mjr dr med. Jedlina-Jacobson, którzy przygotowali okolicznościowy referat. Biskup polowy m.in. powiedział:

Drodzy Rodacy! Naturalne zalety ludzkie podzielić można na dwa rodzaje: na cnoty podstawowe i na cnoty dopełniające, pięknościowe. Na ogół w Polsce przeważają te ostatnie, jak np. wspaniałomyślność, zwłaszcza wobec obcych, szeroki gest, elegancja, kult piękna i idealizmu. Niedoceniane natomiast często bywały cnoty podstawowe, jak np. trzeźwość patrzenia na życie, punktualność, praca systematyczna i wytrwała. Oczywiście te ostatnie wartości są mniej poetyczne od pierwszych, ale za to są zrozumieniem ich bytu, sa fundamentem rzetelnym, na którym dopiero tamto wystawne piętro w życiu państwowym bezpiecznie stać może.

Te więc zalety pierwszego porządku są własnością Wielkopolan. Dopiero na nich buduje Poznaniak górne piętro i umie budować pięknie, praktycznie, a przede wszystkim konsekwentnie. Toteż na pewno obecność najwyższych władz państwowych jest zapowiedzią że przyszła Polska skutecznie czerpać będzie z tego solidnego rezerwuaru sił twórczych. Wielkopolan cechuje konsekwencja: umieli wysnuć wnioski praktyczne z nowych ruchów społecznych, stwarzając sieć nowych organizmów i organizacji, umieli również wysnuć z nauki wiary wniosek o konieczności czynu i tym się tłumaczy, że w Akcji Katolickiej, w instytucjach katolickich dominujace zajmowali stanowiska w Polsce. A głęboka jest ich wiara, oparta o nie wzruszone podstawy Objawienia Bożego. Nie ma u nich: raz tak, raz nie, lecz wszystko jest „tak” w Chrystusie, wiarę nie tylko wyznaja, ale ją tylko praktykują szczerze i wiernie. Gdzież miała myśl katolicka silniejszych, nieugiętszych, konsekwentniejszych i śmielszych obrońców, jak nie w Wielkopolsce? Ludzie, co wszystko budować chcieli na fundamencie Chrystusowym i budować na nim umieli.

Toteż nie dziw, że pewna inna konsekwencja, ze zgubnych wywodzących się doktryn, konsekwencja neopoganizmu germańskiego wymordowała i wybiła w pień razem z chorążymi polskiej myśli narodowej wszystkich działaczy Akcji Katolickiej na ziemiach poznańskich. 
Tym samym wydała świadectwo, że najtrwalszą ostoją Polski sa działacze patriotyczni i religijni, tym samym dowiodła trafności odwiecznego hasła polskiego: „Bóg i Ojczyzna”. Nieugięci i konsekwentni są Wielkopolanie. Ideały narodowe i religijne pragną wprowadzić w czyn [...].

Toteż zwłaszcza dziś, kiedy Rząd nasz wyraźnie oświadcza, iż pragnie budować Polskę naprawdę chrześcijańską. Wielkopolanie i z nimi cały Kraj będą Panu Prezydentowi i Panu Premierowi wdzięczni, jeśli pierwsze symbole tej Polski nowej nosić będa już teraz znamiona chrześcijańskie, mianowicie jeśli Orłowi polskiemu przywrócony zostanie krzyż Zbawiciela, a sztandarom wojskowym Imię Boże.

Będzie to czyn naprawdę godny wielkiej tradycji naszej, będzie pełnym akordem nowej, a przecież tak starej melodii polskiej, częściową nagrodą bohaterskiego porywu Wielkopolan, w rocznicę ich powstania powziętym dokumentem, będzie to czyn o tak doniosłej wadze, że najdalsze pokolenia z wdzięcznością i błogosławieństwem wspominać będą nazwiska tych najwyższych przedstawicieli państwa, co dali wyraz jednomyślności z całym narodem polskim.

A gdy wybije godzina, kiedy Bóg niezbadanymi drogami swoimi zaprowadzi nas do starych siedzib nad Warta, do królewskiego Gniezna, do dumnego Poznania, kiedy nad Bałtykiem powiewać będą amaranty, kiedy wygnane rodziny wasze przy dawnych ogniskach domowych zjednoczą się z wami, tedy na nowo mocną dłonią ujmiecie życie na stanowiskach już kierowniczych i z tą samą jak dotąd prawościa i rzetelnością służyć będziecie Matce, co w was pokładała nadzieję. Na tę drogę wolności, na ten gościniec dziejów królewskich niech wam zawsze błogosławi Bóg!11

Jak zaznaczono w wydaniu pism Gawliny w 1954 r., „apel o przywrócenie krzyża na koronie Orła Białego i wprowadzenie Imienia Bożego na wojskowe sztandary pozostał bez echa"12. Dopiero w 1943 r. na wniosek Naczelnego Wodza gen. Kazimierza Sosnkowskiego (popartego na posiedzeniu Rady Ministrów przez gen. dr. Mariana Kukiela, ministra obrony narodowej) prezydent Raczkiewicz przywrócił odwołanie do Boga na sztandarach wojskowych.

Po południu w sali kinowej Alhambra w Perth, w obecności prezydenta $\mathrm{RP}$, biskupa polowego i ministra obrony narodowej, odbyła się uroczysta akademia. Jak wspominał Witold Józef Leitgeber:

Estrada była przybrana kolorami polskimi, Orłem Białym, emblematami Wielkiej Brytanii i widokiem ratusza poznańskiego. Pierwsze przemówienie wygłasza [Stanisław] Mikołajczyk podkreślając, że na powodzenie powstania wielkopolskiego złożyła się praca wielu pokoleń, która przeorała wszystkie dziedziny życia społeczeństwa i społeczeństwo to zjednoczyła. Następnie Stanisław Jóźwiak nakreślił historię powstania, w którym sam brał udział ${ }^{13}$.

${ }^{11}$ Arcybiskup Józef Gawlina w oczach historyków i duszpasterzy. W 50. rocznice śmierci Biskupa Polowego, red. ks. płk SG dr Z. Kępa, Warszawa 2015, s. 21-22; Józef Feliks Gawlina Biskup Polowy Polskich Sit Zbrojnych, oprac. A.K. Kunert, Warszawa 2002, s. 94-97.

12 J. Gawlina, $Z$ wojny $i$ wygnania. Listy i orędzia pasterskie, kazania, przemówienia, Rzym 1952, s. 46. Zob. też: B. Polak, Biskup Józef Gawlina wobec powstań ślaskich i wielkopolskiego 1918-1921, w: Arcybiskup Józef Gawlina..., s. 22.

${ }^{13}$ W. Leitgeber, W Kwaterze Prasowej. Dziennik z lat wojny 1939-1945. Od Coëtquidan do „Rubensa”, Londyn 1972, s. 89-90. 
Przemawiali też mjr Paluch, mjr dr Jedlina-Jacobson i minister Marian Seyda, członek Komitetu Narodowego w Paryżu od 1917 r., w latach 1939-1941 minister do spraw kraju, a następnie minister sprawiedliwości ${ }^{14}$.

Major Paluch wygłosił referat pt. Elementy sity polskiej $w$ ruchu zbrojnym powstania wielkopolskiego $w 1918 \mathrm{r}$. Swoje wystapienie poświęcone przygotowaniu i przebiegowi walk powstańczych kończył refleksją:

Czytając w prasie niemieckiej opis walk Niemców z nami w obecnej nieszczęsnej wojnie, z którego bił fałszywy czy prawdziwy rytm tryumfalny panzer-dywizji „heimattreuer ostmärker" skurczyło mi się z bólu i żalu serce, że myśmy w tej wojnie nie mieli kilka dywizji pancernych z obsadą bitnych zachodnich Polaków, zaprawionych i twardych w stosunku do Niemców a przede wszystkim nie mających kompleksu niższości. Przyjdzie taka chwila do nas, gdy wrócimy do kraju, równocześnie z kategorycznym imperatywem zlikwidowania raz na zawsze tak zwanej kwestii niemieckiej w Polsce.

Koledzy Powstańcy!

Jestem szczęśliwy, że mogę dzisiaj mówić o naszych zwycięskich bojach o wolność tak odległych czasem a tak bliskich istotą swoja. Gdy powstańcy po trudach bitwy siedzieli przy ogniskach w izbach robotniczych, w chatach chłopskich, czy dworkach ziemiańskich, mówili do siebie: Zrobimy Polskę mocną i bogatą. Będzie nam wszystkim dobrze!

To hasło wraca dzisiaj. A my, ciężko doświadczeni, musimy się wewnętrznie gruntownie przetworzyć, by przy kolebce III Rzeczypospolitej stanać czyści w sumieniach naszych, bo tylko wtedy zdołamy Polskę zrobić lepszą, sprawiedliwą i dla wszystkich Polaków równą ${ }^{15}$.

Paluch nie doczekał zwolnienia z Wyspy Węży, gdyż zmarł 18 VII 1942 r. W 1943 r. Wojsko Polskie - I Korpus w sposób szczególny obchodziło 25-lecie wybuchu powstania w Wielkopolsce. 27 grudnia w katedrze Najświętszej Marii Panny w Edynburgu na uroczystą mszę św. przybyły reprezentacje oddziałów, miejscowa społeczność polska i przedstawiciele dowództwa PSZ, Sztabu Naczelnego Wodza i Ministerstwa Spraw Wojskowych. Kazanie wygłosił ks. biskup polowy Józef Gawlina, przywołując pracę niepodległościową kilku pokoleń Wielkopolan:

Przeciwko zalewowi germańskiemu Raczyńscy wznieśli swą wspaniałą bibliotekę. A gdy wróg was obdarzał nieproszonymi muzeami, teatrami i akademia, umieliście wytworzyć tak wspaniałe tętno kultury polskiej, że jakby siłą magnetyczną przyciągaliście Ślask i Pomorze. Czarem kultury ojców biło od was, a żadna germanizacja nazw, żadne prawo osadnicze, żadna komisja kolonizacyjna, żadna próba protestantyzacji, żaden związek kresów niemieckich nie zdołał was złamać.

Przeciwstawiliście tym pruskim metodom swe doskonałe organizacje polskie i pomoc naukową. I Sokól i Straż Polska i Towarzystwo Czytelni Ludowych i prasa przyczyniły się do podtrzymywania narodowości - mieszczaństwo i kupiectwo polskie rosło, gęstą siecią pokrywały ziemię wielkopolską kółka rolnicze, Banki Ludowe usprawniały stronę materialną dla celów ideowych.

${ }^{14}$ Ibidem, s. 89-90. Zob. też nekrolog: „Przegląd Zachodni” (Londyn) 1967, nr 6.

${ }^{15}$ Fotokopie w zbiorach autora. 
Potym was wywłaszczano i wyganiano z własnej ziemi.

Wtedy wynaleźliście wozy Peplińskich i Drzymałów.

Trud ustawiczny i zmaganie się $\mathrm{z}$ wrogiem wytworzyło $\mathrm{w}$ tym pięknym krzepkim szczepie nie tylko zaciętość, ale przede wszystkim owo głębokie poczucie prawa, które są jego cechami i w własnej Ojczyźnie ${ }^{16}$.

Biskup kończył kazanie z wiarą w zwycięstwo:

I tak jak przed wojną zbieraliście się na apel poległych za wolność Wielkopolski, tak wkrótce staniecie do apelu żywych.

Już nie płomień ogniska zadrga na twarzach waszych - lecz promienie słońca wolności zajaśnieja na waszych obliczach.

Wtedy głuche bić będą werble, lecz nad głowami waszymi zakwitnie radosny hymn polski.

Wtedy Ojczyzna oznajmi nazwiska tych, co obecnie dla niej się zasłużyli i wywoła tych z was, co w dalszym mozole Jej służyć maja.

I każdy odpowie ochoczo: Gotów - pracować do upadłego.

Na ramionach krzepkich i mocną dłonią wydźwigniecie przyszłość waszej ziemi, a do zasług przodków nowe dodacie laury.

A pracom waszym i przyszłości waszej niech błogosławi Bóg Ojciec i Syn i Duch Święty. $\mathrm{Amen}^{17}$.

Po zwolnieniu z więzienia sowieckiego (sierpień 1941 r.) do Londynu przybył Stanisław Celichowski, dowódca kompanii kórnickiej, później III batalionu 11 Pułku Strzelców Wielkopolskich. Przyczynił się do rozpoczęcia zabiegów o konsolidację byłych powstańców wielkopolskich na terenie Wielkiej Brytanii. Prace te prowadził do śmierci w $1947 \mathrm{r}$.

Znaczące poparcie środowisko byłych powstańców zyskało po przybyciu do Londynu gen. Władysława Andersa, owianego sławą dowódcy 2 Korpusu, w powstaniu wpierw szefa oddziału operacyjnego DG, a od 9 lutego szefa sztabu DG. 23 IV 1919 r. objął stanowisko dowódcy 1 Pułku Ułanów Wielkopolskich, przemianowanego później na 15 Pułk Ułanów Poznańskich, którego sztandar marszałek Józef Piłsudski odznaczył Orderem Wojennym Virtuti Militari.

Ułani Poznańscy, zwłaszcza legitymujący się związkami z pułkiem z okresu powstania wielkopolskiego i wojny z bolszewikami, zorganizowali się jeszcze w Rosji, a potem, po ewakuacji, na Bliskim i Środkowym Wschodzie.

Dekorujacc 17 IV 1944 r. Ułanów Poznańskich ${ }^{18}$, gen. Anders przypomniał, iż jest ,to pułk najbliższy jego sercu, gdyż właśnie tym pułkiem dowodził 25 lat temu i w nim zdobył pierwsze polskie odznaczenie bojowe". O faktach tych przypomniał też w Wigilię 1944 r. w dowództwie 15 Pułku Ułanów Poznańskich ${ }^{19}$.

${ }^{16}$ Kazanie J. Eksc. Księdza Biskupa Polowego Wojsk Polskich Józefa Gawliny, „Przegląd Zachodni” 1978, nr 12, s. 17-20.

${ }^{17}$ Ibidem.

${ }^{18}$ Generat broni Wtadystaw Anders. Wybór pism i rozkazów, wstęp, wybór, oprac. B. Polak, Warszawa 2009, dok. nr 42, s. 120-121.

${ }^{19}$ Ibidem, dok. nr 65, s. 161-162. 
W Wielkiej Brytanii Ułani Poznańscy każdego roku uroczyście świętowali doniosłe dla pułku rocznice, ale także święta państwowe: 3 Maja i 11 listopada. W Londynie i innych miastach Wielkiej Brytanii, gdzie znajdowały się większe skupiska Polaków, uroczystości miały podobny przebieg. Rocznice wybuchu powstania wielkopolskiego rozpoczynały się uroczystą mszą św., następnie uczestnicy udawali się na akademię, podczas której głos zabierał gen. Anders lub oficer przez niego upoważniony. Chwila ciszy wspominano poległych i zmarłych ułanów, odczytywano listy od nieobecnych, dzielono się wspomnieniami. Prasa polska, zwłaszcza „Dziennik Polski i Dziennik Żołnierza” i „Przegląd Zachodni”, zazwyczaj publikowała sprawozdania z tych uroczystości.

Informacje o uroczystościach z okazji kolejnych rocznic wybuchu powstania wielkopolskiego do społeczności polskiej w Wielkiej Brytanii docierały przede wszystkim przez prasę i plakaty wywieszane w skupiskach polskich, podpisane przez Zarząd Związku Polskich Ziem Zachodnich (ZPZZ). Ogłoszenia takie publikowano także w „Przeglądzie Zachodnim” m.in. w 1978 r.:

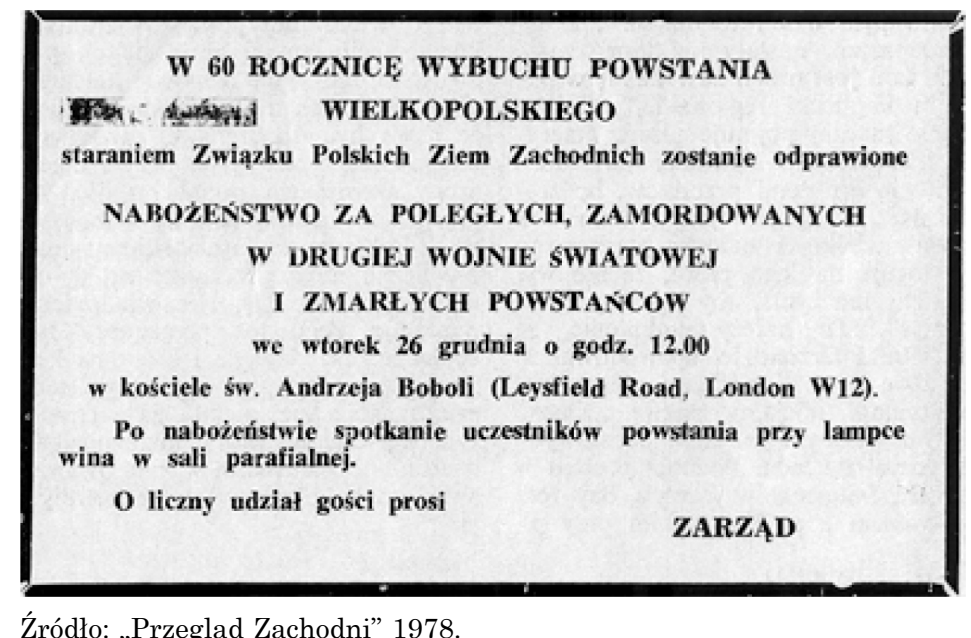

W „Przeglądzie Zachodnim”, w numerze styczniowo-lutowym z 1970 r., ukazało się sprawozdanie z mszy św. w rocznicę wybuchu powstania:

W hołdzie Powstańcom Wielkopolskim

Dnia 28 grudnia 1969 r. odprawiona została w kościele św. Andrzeja Boboli w Londynie msza św. za poległych i zmarłych Powstańców Wielkopolskich. W nabożeństwie wzięli m.in. udział: gen. K. Glabisz, płk. L. Bociański, prezes Zjednoczenia Polskiego w W. Brytanii red P. Hęciak, mjr. F. Rutkowski, mgr Wesołowski oraz członkowie Zarządu ZPZZ - prezes S. Kolańczyk, wiceprezesi J. Kłosok i M. Mela oraz płk. A. Płachta, ppłk. J. Tafelski, M. Mycielski i K. Kubacki. Msza św. odprawiona została w 51-szą rocznicę wybuchu Powstania ${ }^{20}$.

20 „Przegląd Zachodni” 1970, nr 1-2, s. 46. 
Podobnie obchody odbyły się w 1972 r., z których sprawozdanie opublikowane zostało także na łamach „Przeglądu Zachodniego”:

Z okazji 54-tej rocznicy Powstania Wielkopolskiego zebrali się mieszkający w Londynie uczestnicy Powstania oraz grono rodaków na nabożeństwie w kościele pod wezwaniem św. Andrzeja Boboli, które odprawił ks. infułat Władysław Staniszewski. Po nabożeństwie powstańcy i goście udali się do kawiarni parafialnej na tradycyjny Opłatek, który swą obecnością zaszczycił również gospodarz kościoła ks. prałat Kazimierz Sołowiej. Inauguracyjne przemówienie wygłosił Ksiądz Infułat, poświęcając je dwóm rocznicom - Narodzinom Dzieciątka Jezus i Powstaniu Wielkopolskiemu, po czym zainicjował dzielenie się opłatkiem. Doskonale ujęte przemówienie na temat Powstania wygłosił najstarszy z obecnych na Opłatku powstańców, gen. Kazimierz Glabisz, a drugi senior, gen. Antoni Szymański, wyraził radość ze spotkania ze starymi towarzyszami broni i przyjaciółmi, składając przy tej okazji podziękowanie wszystkim tym, którzy przyczynili się do zorganizowania obchodu. Następnie płk Kapuściński podzielił się z obecnymi wspomnieniami z walk powstańczych, a mjr Tadeusz Putz wzniósł toast na cześć obecnych na sali weteranów. P. Kazimierz Majewski złożył hołd powstańcom wielkopolskim w przemówieniu, które podajemy w całości [...]. Pogodną nutę do obchodu wniósł red. Paweł Hęciak, odczytując wyjątek z opowiadania Tadeusza Perkitnego, napisanego w poznańskiej gwarze o udziale młodzieży poznańskiej w bojach powstańczych. Ze wszech miar udany obchód sprawił dużo przyjemności wszystkim obecnym, a szczególnie dostojnym weteranom ${ }^{21}$.

27 XII 1974 r., w 56. rocznicę wybuchu powstania, po uroczystej mszy św. przemówienie wygłosił gen. Kazimierz Glabisz. Tekst wystapienia opublikowany został w prasie polskiej. Generał akcentował:

A gdyby Powstanie Wielkopolskie w ogóle nie wybuchło, a tym samym Wielkopolska odzyskałaby wolność (jak Pomorze) dopiero w styczniu 1920 roku, przebieg naszych granic, zarówno zachodnich jak wschodnich, byłby niechybnie inny niż ten, który został wytknięty przez traktat wersalski, względnie ryski. Wszak nie byłoby w tym wypadku dowodu, że także zabór pruski pragnie niepodległości za wszelką cenę i wszak w sierpniowej bitwie pod murami Warszawy, która zdecydowała o przyszłości Polski, mogłyby uczestniczyć tylko małe oddziały wielkopolskie i pomorskie, a nie cztery dywizje, brygada piechoty i trzy pułki kawalerii, które stanowiły jedną czwarta naszych nacierajacych armii. Czy bez takiego sukursu przebieg tej bitwy i następnej bitwy nad Niemnem byłby tak samo zwycięski, jest co najmniej wątpliwe. Można więc bez uderzenia się i bez samochwały powiedzieć, że obronienie swej niepodległości zawdzięczała Polska w znacznym stopniu wybuchowi wielkopolskiego powstania już w grudniu 1918 roku, które na odwrót oczywiście nie byłoby możliwe, gdyby Królestwo i Małopolska wcześniejszym rozbrojeniem okupantów nie dały dobrego przykładu, a wcześniejsze walki Legionów i formacji wschodnich nie wskrzesiły w masach poznańskich bojowego ducha i przeświadczenia, że „lepsza niepodległość zdobyta niż darowana”. Zwłaszcza że przymusowa służba w znienawidzonej armii pruskiej dała naszym „Kaczmarkom” dobra znajomość żołnierskiego rzemiosła. Tak więc każda dzielnica, nie wyłączając Śląska i Pomorza, których położenie było najtrudniejsze, spełniła - w miarę swoich możliwości - tylko swój obowiązek, gdy wybiła dla niej

21 „Przegląd Zachodni” 1973, nr 1-2. 
stosowna godzina. Toteż [...] nie wolno nam Wielkopolanom wynosić się ponad braci z innych dzielnic. Ale nie wolno też, jak próbowały niektóre koła warszawskie w okresie naszej prawdziwej niepodległości, mierzyć zasług w wydostaniu się spod knuta czy buta zaborców tylko datami kalendarza, bo ryzyko i ofiary nie mniej waża. Oczywiście nie wolno również, jak to próbuje robić obecny reżim warszawski, przypisywać dawniejszym powstańcom wielkopolskim, czy śląskim, wyłącznie antyniemieckiej orientacji. Walczyli oni później o wolność całej Polski i nienawidzili i nienawidzą wszystkich najeźdźców i uzurpatorów - bez względu na to, skąd przyszli i jakim językiem mówią. Miejmy nadzieję, że ich synowie i wnukowie są i pozostaną tak samo nastawieni ${ }^{22}$.

W spotkaniu uczestniczyli byli powstańcy wielkopolscy: płk J. Hildebrandt, płk J. Kapuściński, kmdr T. Mindak, płk S. Tafelski, S., Nowacki, S. (?) Krzysztofowski i gen. K. Glabisz.

Szczególnie uroczysty charakter miały „okragłe” obchody rocznicowe. Odbywały się msze św., akademie, spotkania w szkołach sobotnich, ale wyjątkowa wartość przedstawiały dwie publikacje, które ukazały się w 1968 i w 1978 r., wydane jako numery specjalne miesięcznika „Przegląd Zachodni”. W skład komitetu redakcyjnego w 1968 r. weszli Franciszek Bajorek, Paweł Hęciak, Stanisław Krause, Kazimierz Majewski i Józef Tafelski - działacze ZPZZ w Londynie. Mimo zwiększonych nakładów oba wydawnictwa rozeszły się błyskawicznie. Fragmenty tekstów były też przedrukowane w prasie lokalnej. Wydawnictwo z 1968 r. wstępem opatrzył prezes ZPZZ Krause, a większość tekstów napisali uczestnicy powstania i Marian Seyda, wybitny polityk doby powstania. Specjalny dodatek rocznicowy zamieścił także „Tydzień Polski”.

Po 10 latach ukazał się kolejny numer specjalny „Przeglądu Zachodniego”, liczący 48 stron. Większość artykułów była autorstwa zawodowych historyków: dr. Tadeusza Piszczkowskiego, dr. Zygmunta Wygockiego i prof. dr. hab. Zdzisława Grota z Instytutu Historii Uniwersytetu im. Adama Mickiewicza w Poznaniu.

$$
* * *
$$

Z upływem lat uchodźcze środowisko byłych powstańców wykruszało się. Odchodzili najbardziej aktywni członkowie ZPZZ i koła 15 Pułku Ułanów Poznańskich. W 1961 r. zmarli gen. Zygmunt Łakiński i dr Wojciech Jedlina-Jacobson. Generał Władysław Anders, który skupił szeregi byłych powstańców, odszedł 12 V 1970 r., w rocznicę rozpoczęcia natarcia na masyw Monte Cassino w 1944 r., pochowany wśród swoich żołnierzy na cmentarzu na Monte Cassino. Był żegnany m.in. przez proporzec swego pułku. Zmarł też ppłk Kazimierz Chłapowski, ostatni dowódca poznańskiego pułku w kampanii wrześniowej. Rotmistrz Michał Mycielski odszedł w 1972 r., podobnie jak twórca skautingu wielkopolskiego i dowódca kompanii skautowej - ppłk Wincenty Wierzejewski. Z kolei płk Andrzej Płachta - dusza Koła Lotników,

22 „Przegląd Zachodni” 1974, nr 11-12. 
związany ze środowiskiem byłych powstańców - zmarł w 1974 r. Generał Kazimierz Glabisz, niestrudzony popularyzator wiedzy o powstaniu, odszedł w 1981 r. Jako ostatni z wybitnych organizatorów uroczystości niepodległościowych zmarł w 1993 r. ppłk Józef Antoni Tafelski.

Był to moment kończący historię środowiska powstańców wielkopolskich w Wielkiej Brytanii. Zamknęła się jeszcze jedna karta dziejów polskiego uchodźstwa. Przestano też wydawać „Przegląd Zachodni”, na którego łamach ukazało się kilkadziesiąt artykułów o powstaniu, zarówno o charakterze naukowym, jak i wspomnień powstańców. Dorobek ten stale wykorzystywany jest przez historyków wielkopolskiego czynu zbrojnego lat 1918-1919.

Działalność polskich środowisk kombatanckich w Wielkiej Brytanii stanowiła istotny element integracji społeczności polskiej na Wyspach Brytyjskich. Uroczystości patriotyczne 11 listopada i 27 grudnia podnosiły morale Polaków, krzepiły ich i dawały nadzieję, iż nadejdzie czas odzyskania niepodległości, oczekiwany przez kilka pokoleń uchodźców, także tych z zachodnich ziem: z Pomorza, Wielkopolski i Ślaska.

\section{Streszczenie}

W części wprowadzającej artykułu podkreślono rolę weteranów powstania wielkopolskiego w przygotowaniach do obrony Wielkopolski na wypadek agresji niemieckiej przed 1 IX 1939, udziale byłych powstańców w cywilnej obronie Wielkopolski. Wielu oficerów rezerwy zostało aresztowanych przez NKWD na Kresach Wschodnich RP i zamordowanych wiosną 1940 r. Pozostali przy życiu powstańcy tworzyli zręby konspiracji wojskowej w organizacjach lokalnych i strukturach ZWZ/AK. Ocalała od śmierci z rąk sowieckich grupa oficerów i szeregowych przez Węgry, Rumunię i Jugosławię dotarła do Francji, inni po uwolnieniu z obozów sowieckich wstapili do wojska tworzonego przez gen. Władysława Andersa i przeszli szlak bojowy 2 Korpusu. Po zakończeniu działań wojennych ewakuowani zostali do obozów w Szkocji i większość z nich pozostała na uchodźstwie. Wpierw w Szkocji, a później także w Londynie byli powstańcy przypominali swój zwycięski czyn zbrojny w trakcie rocznic wybuchu powstania i Święta Niepodległości. Spotykali się na uroczystych mszach św., akademiach, uczestniczyli w spotkaniach środowisk pułkowych - zwłaszcza 15 Pułku Ułanów Poznańskich. Ogromną rolę w integracji środowiska byłych powstańców odegrał gen. Anders. Środowisko to aktywne było do końca lat siedemdziesiątych. Jego działalność stanowiła istotny element integracji społeczności polskiej na Wyspach Brytyjskich. Udział w uroczystościach 11 listopada i 27 grudnia podnosił morale Polaków, dając nadzieję, że nadejdzie czas odzyskania niepodległości oczekiwany przez uchodźców.

\section{Independence Day and the Anniversary of the Outbreak of the Greater Poland Uprising Celebrations in the Community of Former Insurgents in Great Britain 1940-1989}

The introductory part of the article emphasises the role of veterans of the Greater Poland Uprising in preparations for the defence of Greater Poland in the event of German aggression before 1 September 1939, the participation of former insurgents in the civil defence of Greater Poland. Many reserve officers were arrested by the NKVD in the Eastern Borderlands 
of Poland and murdered in the spring of 1940. The insurgents who survived formed the foundations of local military underground organisations and in the structures of the Union for Armed Struggle/Home Army (ZWZ/AK). A group of officers and private soldiers who escaped death from the hands of the Soviet troops went through Hungary, Romania and Yugoslavia to France; others, after being freed from Soviet camps, joined the army formed by General Władysław Anders and went along the battle trail with the Second Corps. After the war, they were evacuated to camps in Scotland, and most of them remained in exile. First in Scotland, and later also in London, former insurgents recalled their victorious military actions during the anniversaries of the outbreak of the Greater Poland Uprising and Independence Day. They participated in solemn masses, academies, in meetings of regiment veterans - especially the 15th Poznań Uhlans Regiment. An important role in integrating the community of former insurgents was played by General Anders. The community was actively operating until the end of the seventies. Its activity was an important element of the integration of the Polish community in the British Isles. Participation of the Poles in the festivities on 11 November and 27 December raised the morale of the emigrants, giving them hope that Poland would regain independence.

\section{Bibliografia}

Arcybiskup Józef Gawlina w oczach historyków i duszpasterzy. W 50 rocznicę śmierci Biskupa Polowego, red. ks. płk SG dr Z. Kępa, Warszawa 2015.

Banaszek K., Roman W.K., Sawicki Z., Kawalerowie Orderu Virtuti Militari w mogiłach katyńskich, Warszawa 2000.

Bernaś-Kostynowicz A., Społeczeństwo polskie w wojnie obronnej 1939. Wspótdziatanie ludności cywilnej z wojskiem w okresie zagrożenia $i$ działań wojennych, Warszawa 1978.

Czechowska K., Losy powstańców wielkopolskich ziemi szubińskiej w latach okupacji hitlerowskiej, „Wielkopolski Powstaniec” 2015.

Datner Sz., 55 dni Wehrmachtu w Polsce. Zbrodnie dokonane na polskiej ludności cywilnej w okresie 1 IX - 25 X 1939 r., Warszawa 1967.

Dubas E., Obrona cywilna Wielkopolski w 1939 r., w: Z lat wojny i okupacji, red. L. Grot, Warszawa 1974, s. 15-40.

Gomolec L., Obrona cywilna Kłecka w 1939 roku, Poznań 1966.

Józef Feliks Gawlina Biskup Polowy Polskich Sit Zbrojnych, oprac. A.K. Kunert, Warszawa 2002.

Kaliska-Brzezichowa J., Obrona Inowroctawia we wrześniu 1939 r. i poczatki okupacji hitlerowskiej (wrzesień-październik 1939 r.), „Zeszyty Naukowe INS” (Koszalin) 1986, z. 6.

Kazanie J. Eksc. Księdza Biskupa Polowego Wojsk Polskich Józefa Gawliny, „Przegląd Zachodni” 1978, nr 12.

Ludność cywilna Kłecka w obronie Ziemi Gnieźnieńskiej. Studia z historii Ziemi Gnieźnieńskiej w latach 1919-1939, red. B. Polak, Poznań 1980.

Polak B., Polak M., Obchody rocznic powstania wielkopolskiego w Wielkiej Brytanii (cz. 1), „Wielkopolski Powstaniec” 2018.

Polak B., Polak M., Powstańcy wielkopolscy 1918-1919 po II wojnie światowej w Wielkiej Brytanii, „Wielkopolski Powstaniec” 2016; cz. 2, 2017.

Polak B., Powstańczy rodowód polskiej konspiracji wojskowej w Wielkopolsce, 1939-1942, w: Z dziejów polskiej konspiracji wojskowej na tzw. ziemiach wcielonych do Rzeszy 1939-1945, red. nauk. B. Polak, Koszalin 1988, s. 52-121.

Polak B., Społeczeństwo Wielkopolski w obliczu zagrożenia niemieckiego (kwiecień-sierpień 1939 r.), w: Udziat Wielkopolan w wojnie obronnej 1939 r., red. P. Bauer, Kościan 1975, s. $45-80$. 
Polak B., Udziat ludności cywilnej w obronie Wielkopolski 1939, Koszalin 1989.

Powstańcy wielkopolscy. Biogramy uczestników powstania wielkopolskiego 1918-1919, red. nauk. B. Polak, t. I-XV, Poznań 2005-2018.

Stownik biograficzny powstańców wielkopolskich 1918-1919, red. nauk. A. Czubiński, B. Polak, Poznań 2002.

Zbrodnie Wehrmachtu w Wielkopolsce w okresie zarzqdu wojskowego (1 września - 25 października 1939), red. A. Galiński i in., Kalisz 1986.

Biogr a m: Bogusław Polak - prof. zw., historyk, politolog i archiwista. Autor ponad 30 monografii samodzielnych, 40 współautorskich, redaktor ponad 50 prac zbiorowych i autor ponad 500 artykułów, kilkuset biogramów itd. Do 1978 r. pracownik naukowo-dydaktyczny Instytutu Historii Uniwersytetu im. Adama Mickiewicza w Poznaniu. Od 1979 r. na Politechnice Koszalińskiej. Zajmuje się historia polityczno-wojskową Polski XX w., źródłoznawstwem najnowszym, historią Polskich Sił Zbrojnych na Zachodzie, rolą Polaków w integracji Europy w XX w., biografistyką i dziejami uchodźstwa polskiego w Wielkiej Brytanii. E-m ail: boguslaw.polak@tu.koszalin.pl. 